\title{
Governing for Creativity
}

\author{
GER H A R D CASPER \\ Freeman Spogli Institute for International Studies, Stanford University, 616 Serra \\ Street, Stanford, CA 94305-6060, USA. Email: gcasper@stanford.edu
}

\begin{abstract}
The paper addresses the question of how, in a research-intensive university, choices should be made to determine strategies that are appropriate for ambitious and creative institutions committed to both teaching and research at a high level. The paper calls for accountable real leadership at the university level and at lower levels. It also calls for organizational flexibility and flexibility in the allocation of material and immaterial resources.
\end{abstract}

'The search to know' is a good phrase to summarize what universities are primarily about. It captures why there are students (they want to learn, to know something), what faculty are engaged in as they develop courses, pursue teaching and do research. The combination of these three elements (teaching, learning and research) and the vertical integration of various age groups differentiate universities from most other institutions. An even more abstract way of making the point is to say that universities are institutions that are dedicated to the tradition of existing knowledge and the creation of new knowledge.

How is this to come about? One of my predecessors as president of Stanford, the great Wallace Sterling, who had much to do with Stanford's rise, once, asked about his 'philosophy' of higher education, said: 'My philosophy ... is not to develop a philosophy of education, but instead to try to find the best possible faculty; then to upgrade the breadth and variety of students, and provide needed physical plant; and then sit back and see what results.' I confess that this view of the matter is very close to my own. However, undoubtedly there is more to be said.

The literature on the role of universities in modern societies is huge. It covers the choice and admission of students and fee levels, the choice of faculty and curricula, the choice of research agendas, the choice of investments in programmes, infrastructure and funding sources, the choice of knowledge transfer strategies, the choice of ways to deal with the challenges of globalization, and so on, and so on.

Myriad choices have to be made in order to determine strategies that are appropriate for ambitious and creative universities. The question is: who makes these choices? The topic I have been assigned is 'Governing for Creativity'. I am inclined to 
call my topic simply 'good governance'. While it is true that creativity is not a primary goal in all universities, in a university worth its salt, creativity is what should ideally shape teaching, learning and research. In my remarks about governance, I shall focus exclusively on research-intensive universities, that is, universities that are committed to both teaching and research at a high level.

The way in which universities are organized and governed, of course, differs greatly from one country to another. There is, however, an increasing consensus worldwide on how universities should be governed. This emerging consensus first of all views the role of the state, the role of government, as primarily that of facilitator, not that of regulator or decision-maker. I am not suggesting that many governments are part of the emerging consensus.

Economic analysis has recently offered evidence in support of the desirability of university autonomy and competition. Philippe Aghion and co-authors have attempted to relate the output of public universities in Europe and the United States to the degree of autonomy and the accountability that is achieved by competition among universities. ${ }^{1}$ Performance is measured in terms of the Shanghai and Taiwan rankings of universities worldwide. In the case of the United States, the authors also look at the effect of a state's education investments on research publications and number of patents (taking autonomy and competition into consideration). Patents are, of course, one measure of creativity. The authors' analysis suggests that university autonomy and competition are positively correlated with university output.

In order to determine the extent of university autonomy, Aghion and his co-authors asked the following questions:

- Does the university set its own curriculum?

- Does the university select its own students or is there centralized allocation?

- To what extent does the university select its own professors?

- How much does the state intervene in setting wages?

- Are all professors with the same seniority and rank paid the same wage?

- Does the university's budget need to be approved by the government?

- What share of the university's budget comes from core government funding?

- What share comes from research grants for which the university must compete? (Ref. 1, p. 17)

To test how open and competitive hiring for faculty positions is, they also asked what proportion of the university's professors have their doctoral degrees from the university itself.

Aghion and his fellow authors sum up by stressing that their evidence does not suggest that autonomy per se is a panacea. Instead, autonomy and the accountability that arises through competition go together. They write:

Our evidence on the complementarity between autonomy and external discipline is particularly telling for the role of competitive grants. Indeed, one important lesson from our analysis is that competition for basic research funding restructures the 
environment for universities, inducing them to focus on whether their research is compelling and productive. Such a focus motivates them to make strategic choices that improve the efficiency with which they turn research budgets into research results. (Ref. 1, p. 45)

Otto Hüther and Georg Krücken distinguish five approaches to governance: government regulation, government goal setting, autonomous decisions by university leadership (hierarchies), faculty self-governance, and competition. ${ }^{2}$ In reality, these five approaches are, of course, combined at various levels of intensity. I take competition for faculty, students, and external financial support (especially research awards) for granted and consider it a since qua non for creativity. However, my question is what internal governance structures make it possible for universities to be competitive, innovative, creative.

A university, whether public or not-for-profit private, is different from for-profit businesses in that it does not have owners in any ordinary sense of the word. In the case of public universities, including public foundation universities, one might argue that ultimately ownership can be traced to the state. However, state ownership is an abstraction that ignores the complex interplay of government officials, administrators, faculty, students, staff, alumni, parents, and interest groups that influence the choices made by even fully government financed public universities.

The one group that comes closest to displaying characteristics of ownership in both private and public universities is, of course, the faculty. When General Dwight D. Eisenhower, in 1948, became president of Columbia University, he congratulated Isaac Rabi, a physicist, on his recent Nobel Prize. Eisenhower said that he was always happy to see 'one of Columbia's employees honored'. Professor Rabi supposedly responded: 'Mr. President, the faculty are not employees of the University - they are the University.'

While less than complete, the assertion also contains more than an element of truth. It is useful to remind ourselves that the most crucial decisions - the initiation of faculty appointments, the choice of research projects, essential features of the curriculum, and, in many instances, the selection of students - in the leading universities around the world are or should be mostly under the control of faculty, because that is where subject-matter expertise lies. Few businesses have as many highly differentiated 'product lines' as do universities. The almost unlimited multiplicity of actual or possible endeavours is one reason why university decision-making needs to be both decentralized and centralized at the same time: what $M$. Henkel has called 'centralized decentralization'. ${ }^{3}$

The organizational characteristic of universities as 'structured anarchy' poses two major difficulties. One is accountability, the other concerns taking initiatives and achieving coordination. The dilemma lies in the difficulty of establishing accountability for the commissions and omissions of highly diffuse jurisdictions and for the choices a university makes. When responsibilities are as widely scattered as they are in universities - among individuals, research groups, departments, committees, deans, academic senates - the danger is always that no one is responsible, because everyone is, and everyone can hide behind the designation 'the' university, 'the' faculty, or 'the' 
administration. In the United States, the default position is frequently to hold the university president accountable. That is fine as long as one grasps the limits of presidential power.

The other difficulty lies in taking initiatives and achieving coordination. The issue has been well summarized by the late Burton Clark, a leading sociologist of higher education.

[T]o contain conflict and provide some minimal clarity of purpose, the coordination of organizational structures and cultures takes on heightened importance. It is no simple matter in the mass university to commit effort in three or more major directions that are not mutually supportive; to fashion acceptable channels that constrain the interest group struggle; to provide accountability among basic units strongly impelled to self-steer; and to assert symbolic ties that bind the many parts into a whole. $^{4}$

To accomplish all this, it is necessary to have real leadership at the university level, real leadership at the level of intermediate administrative entities, such as schools, and real leadership in departments and institutes - what Clark calls 'the basic units' (Ref. 4, pp. 205, 225, 239). Appointments to leadership positions (presidents, deans, chairs) must be based on merit alone and should be for fixed terms (a renewable five years is a reasonable figure). The length of the term of office of high level university leaders is of great importance: if they are too transitory, they will ordinarily lack understanding of the issues and they will not be really reckoned with by faculty and other university citizens. At every level there should be job descriptions that define, to the extent possible, tasks and responsibilities. There must be accountability for performance in administrative jobs within the university to colleagues and to those higher in rank.

The primary task of the leadership of a university is constantly to ask whether something can be done better. Without a measure of flexibility, at all levels of the university, to apply material and immaterial resources where they can produce the greatest possible intellectual gain, little can be accomplished. All levels must make use of such flexibility. Active management at the very top is absolutely insufficient unless deans and the chairpersons of departments and institutes complement it. For this the leadership must form teams and there have to be informal checks and balances. On the whole, the effectiveness of a university's simultaneously hierarchical and flat system depends on the leadership's willingness to consult and communicate, but, of course, also on its willingness to make decisions, especially choices.

Among the greatest challenges that universities face is the challenge to develop and maintain institutional characteristics that make a particular university part of the worldwide republic of learning and yet distinguish it from other institutions through its academic creativity and through some measure of coherence and a sense of identity and loyalty on the part of those who belong to it now and also those who did belong to it in the past.

A university's competitive strength is, to a large extent, a function of its capacity to combine encouragement and freedom for the multiple pursuits of its faculty and students as they interact with one another. I am well-known for believing that this is 
most easily accomplished in a university that is clearly based on the notion of a synthesis of teachers and students, a dialectical relationship between learning and research.

The students' search to know and the faculty's search to know are interdependent: It is the faculty's task to inform and challenge the students, and it is the students' task to question and challenge the faculty in their academic pursuits. At least since Wilhelm von Humboldt, this synthesis of teachers and students has been widely understood to provide optimal conditions for creativity. ${ }^{5}$

'One unique feature of higher intellectual institutions,' Humboldt wrote in 1810, 'is that they conceive of science and scholarship as dealing with ultimately inexhaustible tasks; this means that they are engaged in an unceasing process of inquiry' (Ref. 5, p. 243).

It was in connection with his emphasis on the 'unceasing process of inquiry' that Humboldt, rather unsentimentally, concluded that in higher education 'the teacher does not exist for the sake of the student' but that 'both teacher and student have their justification in the common pursuit of knowledge.' I quote:

The teacher's performance depends on the students' presence and interest - without this science and scholarship could not grow. If the students who are to form his audience did not come before him of their own free will, he, in his quest for knowledge, would have to seek them out. The goals of science and scholarship are worked towards most effectively through the synthesis of the teacher's and the students' dispositions. The teacher's mind is more mature but it is also somewhat one-sided in its development and not quite as lively; the student's mind is less developed and less committed but it is nonetheless open and responsive to every possibility. The two together are a fruitful combination. (Ref. 5, pp. 243-244)

In order to determine whether a university 'governs for creativity', one needs to ask how the university connects teaching and student learning with its research activities. It goes without saying that one other question that needs asking concerns the extent to which the university facilitates transdisciplinary research. In this regard, permit me to conclude my remarks with an anecdote.

In 1998, when I served as president of Stanford, I was visited by a group of faculty representing such disciplines as biology, developmental biology, biochemistry, neuroscience, genetics, physics and engineering. I knew all the participants and their academic standing. They urged me to provide the organizational and physical infrastructure for collaborations at the intersection of science, medicine and engineering. They basically wanted to create a cauldron of creativity and innovation and asked me to build a new kind of laboratory where flexible spaces would be assigned to research projects on a non-permanent basis and equipment would be shared.

When I asked what the enterprise would be called, the answer was 'Bio-X'. I responded by pointing out that it would be difficult to raise money for the unknown. Being merely a law professor, I thought a label like 'Biomedical Sciences and Engineering' was called for. At a second meeting, the faculty group insisted on 'Bio-X' in order to stress the creative open-endedness of what they were trying to accomplish. And Bio- $\mathrm{X}$ it is today, almost 20 years later. 
We retained Norman Forster to design a three-story, 14,000 square metre building that I consider one of the most dynamic laboratory facilities in the United States. The centre was completed in 2003 and is named for its major donor, James Clark, of Silicon Graphics and Netscape fame. In addition to modern lab space, Bio-X provides seed grants, graduate fellowships, undergraduate research programmes, and venture funds to drive research and educate a new generation of interdisciplinary scientists. Hundreds of Stanford faculty from around the university, graduate, and undergraduate students are now affiliated with Bio-X.

Why am I telling this anecdote? Richard Clark once wrote: the problem of responding to inevitable complexity 'is a problem of organization, of structuring and restructuring of the university.' Bio-X as an idea began with collaboration of two researchers, a biochemist from the Stanford School of Medicine, James Spudich, and a Stanford physicist, Steven Chu. Then faculty from across the university formed the steering committee that convinced me. It took two university presidents in succession, provosts, the deans of three schools, and department chairs all to collaborate and be willing to structure and restructure. An additional result has been a bio-engineering department that is part of both the engineering and the medical school. Governing for creativity means the willingness to make choices and to reorganize dynamically according to the choices that have been made. It also means, or presupposes, the willingness of members to identify with and to work for their university's institutional well-being.

\section{References and Notes}

1. P. Aghion, M. Dewatripont, C. Hoxby, A. Mas-Colell and A. Sapir (2010) The governance and performance of universities: evidence from Europe and the US. Economic Policy, 25, pp. 7-59.

2. O. Hüther and G. Krücken (2018) Higher Education in Germany. Recent Developments in an International Perspective (Berlin: Springer).

3. M. Henkel (1999) The modernisation of research evaluation: The case of the UK. Higher Education, 38, pp. 105-122.

4. B.R. Clark (1995) Places of Inquiry. Research and Advanced Education in Modern Universities (California: University of California Press), p. 248.

5. W. von Humboldt (1970) On the Spirit and the Organisational Framework of Intellectual Institutions in Berlin. Minerva, VIII, pp. 242-250.

\section{About the Author}

Gerhard Casper is President Emeritus of Stanford University and a Senior Fellow at the Freeman Spogli Institute for International Studies at Stanford. He studied law at the universities of Freiburg, Hamburg, and Yale, then returned to Freiburg, where he earned his PhD in 1964. After an initial teaching position at the University of California at Berkeley, Casper was recruited two years later by the University of Chicago, where he spent 26 years, served as dean of the law school, and, in 1989, was appointed provost, a post he held until he became president of Stanford University in 1992. 